\title{
ORCZY EMMA MESEKÖNYVE
}

\section{FAIRY TALES BY BARONESS ORCZY}

\author{
Bárdos Dóra ${ }^{1^{*}}$ \\ ${ }^{1}$ Ceglédi Kossuth Lajos Gimnázium, Cegléd, Magyarország \\ https://doi.org/10.47833/2020.3.ART.001
}

\section{Kulcsszavak: \\ Orczy Emma \\ tündérmesék \\ A Vörös Pimpernel \\ Keywords: \\ Baroness Emmuska Orczy \\ fairy tales \\ The Scarlet Pimpernel}

\section{Cikktörténet:}

Beérkezett 2020. január 10.

Átdolgozva 2020. június 20.

Elfogadva 2020. június 30.

\begin{abstract}
Összefoglalás
Orczy Emma bárónő Magyarországon született, mégis angol írónő lett belöle. Nevét ma is ismeri az egész világ, hiszen ő alkotta meg a romantikus kalandhős, a Vörös Pimpernel alakját. Első igazi müve azonban egy mesekönyv volt, amelyben szándéka szerint régi magyar tündérmeséket osztott meg olvasóival. Tanulmányomban ezeket szeretném bemutatni.
\end{abstract}

\begin{abstract}
Baroness Emmuska Orczy was born in Hungary, but she was an English writer. She is best-known for her most famous, romantic historical novel, The Scarlet Pimpernel. But her first book was Old Hungarian Fairy Tales, a collection of eight Hungarian tales. These are what my paper are about.
\end{abstract}

\section{Bevezetés}

Ha arra kérnénk az utca emberét, sorolja fel, szerinte melyik az a néhány magyar író, akit nemzetközileg a leginkább ismernek napjainkban, nagy összegben fogadni lehetne rá, hogy egyikőjük sem nevezné meg köztük Orczy Emmát. Pedig, bármennyire is meglepő lehet ez, ő az egyetlen magyar születésủ író, akiről krátert neveztek el a Vénuszon. A munkáiból készült első megfilmesítés 1916-os, a legutolsó azonban mindössze 2004-es. Színdarabját először 1903-ban mutatták be, utoljára viszont 1997-ben készült $A$ Vörös Pimpernel című müvéböl musical, amelyet aztán 2014-ig folyamatosan játszottak a világ minden részén, Japántól Finnországig. Bármely internetes könyváruház kínálatát böngészve szembesülhetünk vele, hogy minden prózai müvét megvásárolhatjuk friss papírkiadásban vagy e-bookban. S amikor a nagyközönségnek szóló digitális információtárolás hajnalán, 1995-ben, az USA-ban megjelent egy Over 2000 Great Works of World Literature című $C D$, erre egyetlen magyar író művét tették fel: Orczy Emmáét.

Elmondható tehát, hogy Orczy Emma életműve és hatása itt van velünk ma is, születése után 155 évvel. Függetlenül az irodalmi, vagy a magyar irodalmi kánonban elfoglalt helyétöl, ő az egyik legismertebb (ha nem a legismertebb) magyar író, amit csak részben magyaráz az, hogy angolul alkotott. Éppen ezért érdekes, hogy magyar nyelven szinte nem létezik a műveivel kapcsolatos irodalomtörténeti-irodalomelméleti vizsgálódás. [1] Rövid tanulmányom nem tudja és nem is kívánja mindezt pótolni. Csak elindulni szeretne az úton, az életmü egyetlen apró szeletére vetve egy pillantást: Orczy Emma régi magyar tündérmeséire, amelyek eredetileg 1895-ben láttak napvilágot Londonban, még azelőtt, hogy szerzőjük elismert és befutott szerzővé vált volna.

\section{Az életmű és hatása}

Orczy Emma, Báró Orczi Orczy Bódog és Szentegyedi és Czegei Wass Emma leánya, teljes nevén Orczy Emma Magdolna Rozália Mária Jozefa Borbála bárónő Magyarországon, Tarnaörsön

\footnotetext{
* Kapcsolattartó szerző: Dr. Bárdos Dóra. Tel.: +36 30609 9449,

E-mail cím: dora.bardos@gmail.com
} 
született 1865-ben. Apja, aki a Nemzeti Színház intendánsaként, Liszt, Wagner, Gounod ismerőseként kortársaiénál szélesebb látókörrel rendelkezett, 1868-ban egy riasztó helyi parasztlázadás hatására elhagyta Magyarországot. A család Brüsszelbe, majd Párizsba költözött, 1880-ban pedig Angliába. Orczy Emma kiváló művészeti képzést kapott: kezdetben zenét tanult, a festészethez azonban nagyobb tehetsége volt, így tanulmányait a Heatherley School of Fine Arton fejezte be. Pályája elején a Királyi Művészeti Akadémián is kiállították néhány művét, s a festészet ismertette össze későbbi férjével, Montague MacLean Barstow-val, a fiatal rajzolóval. A bárónő és a lelkész fia 1894-ben házasodott össze, 1899-ben gyermekük született, John.

Bár tizenöt éves koráig Orczy Emma állítólag egyáltalán nem tanult meg angolul, később mégis az irodalom hozta meg számára a sikert. Röviddel fia születése után kezdett el regényeket írni, bár első könyve, az 1899-es The Emperor's Candlestick's (magyarul: Ferenc József gyertyatartói, 1926) még nem volt igazán népszerü. Az áttörést máig legnagyobb hatású figurája, a Vörös Pimpernel megteremtése jelentette. Orczy elöször színdarabot írt a témából, amely 1903-as első előadását követően fokozatosan akkora népszerüségre tett szert, hogy 1905-ben, West End-i bemutatója után az írónő könyvvé formálta. A többi már történelem: az 1905-ös The Scarlet Pimpernel címü regényt (magyarul: A Vörös Pimpernel, 1907) harmincöt év alatt tíz folytatásregény, két novelláskötet, három spin-off történelmi regény és egy esszékötet követte, $s$ máig alapvetően ez teszi felejthetetlenül népszerüvé és maradandóvá Orczy Emma irodalmi hagyatékát. $E$ könyvekböl született a legtöbb adaptáció is: színdarab, musical, továbbá az Internet Movie Database által számon tartott 38 Orczy-mü nyomán forgatott mozifilm, televíziós változat és tévésorozat több mint a fele.

$A z$ írónőnek élete végéig szinte minden évben megjelent egy-egy regénye vagy elbeszéléskötete így összesen mintegy hatvanegy könyvet írt, melyeket több mint tizenöt nyelvre fordítottak le. Leginkább a történelmi regény és a történelmi kalandregény müfajában alkotott, amelybe a Pimpernel-regények is tartoznak.

Azonban detektívtörténeteket is írt, sőt, napjainkban részben épp ezek létezése eredményezi, hogy szívesen foglalkozik műveivel a (nem magyar) irodalomtörténeti kutatás. Lady Molly Robertson-Kirk nevü hőséröl szóló bünügyi novelláiban a krimiirodalom történetében először léptetett fel hivatásos nyomozónőt. Lady Molly a Scotland Yard detektívje, kalandjait pedig szintén nő segítőtársa, Miss Mary Granard, tehát egy női Watson beszéli el. Szintén jelentős, új narrációs megoldással kísérletező krimitörténetei voltak a például a The Old Man in the Cornerben (1908, magyarul: A rejtélyes sarok, 1929) szereplő elbeszélések. Ezek detektívje, az Öregember minden alkalommal ugyanabban a teázóban találkozik az újságíró Polly Burtonnel, meghallgatja az elbeszélését egy bűnesetröl, majd azonnal megfejti azt: vagyis az armchair-detektív, a karosszékéből ki sem mozduló kriminyomozó őstípusa. Harmadik nyomozófigurájában, az 1928-ban megalkotott ír ügyvéd-detektívben, Patrick Mulliganben pedig sokan látják Erle Stanley Gardner legendássá vált figurájának, Perry Masonnek az egyik mintáját. [2] Nyilvánvalóan egyedi felfogása volt a detektívtörténetröl, hiszen mindig elbeszélés-gyüjteményekben, novellákban gondolkodott, holott más müfajokban vaskos regényeket publikált. Mégis, egyértelmü, hogy több szempontból is elképzelhetetlen nélküle a krimiirodalom története. Ráadásul érdemeit nem utólag vették észre, hiszen saját korában is népszerủ volt bünügyi történetek írójaként: még Agatha Christie is tisztelgett elötte Partners in Crime (1929, magyarul legfrissebben: Bünszövetkezetben, 2012) címü regényében, ahol az Öregembert olyan nyomozókkal állította egy sorba, mint Sherlock Holmes, Brown atya vagy Hercule Poirot. [3]

Legmaradandóbb alkotása azonban vitathatatlanul a Vörös Pimpernel, vagyis az elegáns, gazdag, világlátott, ám felületes, üresfejü és unott angol arisztokrata, Sir Percy Blakeney, a régensherceg, a leendö IV. György kebelbarátja, a szalonok szellemdús központja, és az incroyabledivat szélsőséges megoldásainak kifinomult követője. Aki persze valójában bátor, merész, tehetséges és hazafias, igazi angol hős, hisz élete kockáztatásával folyamatosan halálos veszélybe került franciákat menekít ki a forradalmi Franciaországból a köztársasági terror idején. Orczy Emmának köszönhetőn, Sir Percyvel született meg tehát az irodalomban a kétarcú hős e típusa. Aki elökelő, vagy legalább gazdag családból származik, ami nagy mozgásteret biztosít számára, aki mindig a szabadság, az emberi jogok és az emberi élet védelmében cselekszik, $s$ aki épp ezért ostobának, nagyzolónak, gyávának, passzívnak tetteti magát, hogy senki se gyanakodjon rá, amikor bölcsen, ötletesen, hősiesen és bátran harcol a gyengékért és az elnyomottakért. Ez a 
kalandhőstípus a későbbiekben Johnston McCulley Zorrójában élt tovább, s gyakorolt óriási hatást az amerikai szerzőkre. Igaz, arról, hogy a fekete köpenyben és álarcban harcoló, pompásan vívó, közben azonban az idegesítően piperkőc és kínosan gyáva nemes úrfit alakító Don Diego Vega figurájához sokban Orczy Emma hőse adhatta az ötletet McCulley-nak, annak ellenére elfeledkezett egy idöre az irodalomtörténet, hogy mára már ismét egyértelmü. Mindez pedig azért különösen fontos, mert az már hosszabb ideje köztudomású, hogy Zorro számos pulp-figura kiformálódásához járult hozzá az 1930-as években feltűnő Shadowtól (akit Walter B. Gibson alkotott meg, s sokan az első szuperhősnek tartják, aki még nem képregényekben mutatkozott be) egészen a Bob Kane által 1939-ben kitalált Bruce Wayne/Batmanig, vagy akár (a már sci-fis eredettörténettel rendelkező, ám a pimperneli, csetlő-botló alteregót nagyon is megtartó) Supermanig. [4] Vagyis bizonyos szempontból Orczy Emma, a magyar születésű írónő alapvető ötlettel járult hozzá mindezeknek a ma kifejezetten filmes, képregényes és könyves reneszánszukat, sőt, újjászületésüket élő figuráknak a keletkezéséhez. A krimitörténeti mellett talán ez a legmaradandóbb hatása Orczy Emma életművének.

Felmerül azonban a kérdés, ha külföldön ennyire népszerü szerző ma is, annak ellenére, hogy 1947-ben, vagyis immár hetvenhárom éve elhunyt, akkor vajon a magyar irodalomtörténet miért nem vesz róla tudomást.

A kérdés megválaszolása nem lehet a tanulmány feladata, legfeljebb annyiban, amennyiben kapcsolódik az Orczy-tündérmesék hazai elfelejtettségéhez. Az azonban leszögezhető, hogy önmagában az, hogy Orczy Emma nem magyarul írt, nem lehet elégséges indok, hiszen Agota Kristof vagy Kertész Imre legfontosabb müvei sem ezen a nyelven születtek meg. Természetesen kínálkozó válasz lehet az, hogy az életmű nem magasirodalmi: több irodalomelméleti felfogás szerint sem tartozik a szépirodalom tárgykörébe a krimi vagy a kalandtörténet, az írónő két kedvence. Azt azonban, hogy Orczy Emma miért nem jelenik meg a magyar irodalmi kánonban egyáltalán, ez sem magyarázza önmagában: hiszen ma is olvasunk Agatha Christie-t, Conan Doyle-t, sőt, jelenleg nagy felvirágzása van magyar nyelven az angolszász kalandos, borzongató és ősfantasyelbeszéléseknek is a 20. század első feléböl. [5] Magyarázatot jelenthet természetesen a politika: 1945 után évtizedekig nem lehetett kiadni Magyarországon Orczy-regényt, különös tekintettel $A$ Vörös Pimperne/re, amelynek forradalomképe nem felelt meg a marxista történelemszemléletnek. Csak 1990-ben, 45 év után kerülhetett a boltokba Orczy-könyv. Ám tény, hogy Orczy Emma előtte sem volt különösen népszerủ magyar nyelven. Szórványosan (és hiányosan, húzásokkal) fordították le munkáit, öt Pimpernel-regény és hét egyéb kötet jelent meg a tollából. Ám ez a tizenkét mű is rendkívül hosszú idő alatt jutott el a magyar könyvpiacra: az első 1907-ben, az utolsó (első kiadásában) 1930-ban. 1930 után már csak a Pimpernel-regényeit adták ki újra, de újabb munkákat nem magyarítottak töle. Holott az írónő ekkor még nemcsak élt, de az angol olvasóközönség előtt népszerü volt, s még javában publikált friss regényeket. Mintha a hazai olvasóközönségnél hiányzott volna valami, ami az angol nyelven olvasókat megfogta az életmüben... [6]

Mindez pedig azért lehet fontos, mivel a Régi tündérmesék esetében ez nem így volt: a magyar kiadás már az angol után három évvel megjelent, miközben Orczy ekkor még ugyanúgy nem volt befutott szerző új hazájában, mint az eredeti angol változat megjelenésekor. Ráadásul a fordításhoz írt előszó egyfajta kulturális nagykövetként állította be őt, aki meseíró munkásságával jó hírét kelti hazánknak a nagyvilágban. Vagyis az Orczy Emma első munkáját kézbe vevő magyar érdeklődő 1898-ban úgy érezhette, egyfajta hazafias cselekedetet hajt végre, amikor büszke olvasójává válik a messzi Angliában magyar meséket író és felidéző, magyar származású írónőnek. Ezt a gondolatot azonban nem követte folytatás: mint írtam, A Vörös Pimpernel csak 1907-ben, a következő kriminovella-gyűjtemény pedig már csak 1918-ban látott napvilágot, s paratextuális környezete sem sugallta, hogy - miként azt a Régi tündérmesék előszóírója még megfogalmazta -, Orczy Emma hazaérkezne igazi otthonába szövege lefordításával. [7] Hogy a megváltozott felfogásnak mi lehetett a pontos oka, további kutatást igényelne.

\section{Orczy Emma mesekönyve}

Az írónő 1895-ben jelentette meg mesegyüjteményét, Old Hungarian Fairy Tales címen: ez volt élete első kiadott könyve. A múvet férjével, az illusztrátor Montague Barstow-val alkotta meg, $s$ bár az angol kiadás adatai szerint nem válik el egészen, mindketten szerzők (adaptálók) és 
illusztrátorok-e, a legvalószínübb, hogy az álomszép képekért, illusztrációkért és könyvdíszekért Barstow, a szövegért pedig Orczy Emma felelt. Erre utal, hogy az előszóban egyedüli szerzőként mutatkozik be. A díszes borítójú könyv a Dean \& Son/Wolf \& Co. kiadásában látott napvilágot és nyolc mesét tartalmazott. Három mesét még ugyanebben az évben külön képeskönyvben is kiadtak: kettőt (Uletka and the White Lizard, The Enchanted Cat) az eredetivel megegyezö, a harmadikat pedig új címen (The Suitors of the Princess Fire-Fly helyett mint Fairyland's Beauty). A meséknek (a második kivételével, amelyé véletlenül maradhatott ki), az angol kötet megadta a magyar címét is. Ezek - betühíven közölve, de jól látható, hogy az angol nyomdász tévesztéseitöl eltekintve helyes a magyarságuk - a következők: Uletka and the White Lizard - Uletka a kilencz törptéknél, The Suitors of the Fire Fly, The Twin Hunchbacks - A Rét törpe, Mr Cuttlefish's Love Story - Sengeralatti szerelem, Forget-me-not - Nefelejts, The Enchanted Cat - A büvös macska, The Wishing Skin - $A$ vardzs bör, „That's Not True”- Az mdr nem igaz! Úgy vélem, fontos és érdekes például, hogy az $A z$ már nem igaz! felkiáltás után az angol kötetben ott a - helyes - felkiáltójel. A könyvnek 1970-ben jelent meg újabb angol kiadása, egy reprint, s nagy valószínűséggel ismét népszerü vált, mivel még napjainkban is számos helyen fellelhető az interneten. A mesegyújteményt azóta e-bookban és printon-demand formában is meg lehet vásárolni, illetve teljes terjedelmében, az eredeti illusztrációkkal elérhetö a The Baldwin Project keretében is a neten.

Nálunk azonban nem alakult ilyen szépen a kiadástörténete. 1898-ban, tehát nagyon gyorsan a megjelenés után kiadta az Athenaeum, kétféle színű borítóval is, s belül az eredeti kötettervvel, illusztrációkkal. Címe a következő lett: Régi Tündérmesék. Ujra elmondja Báró Orczy Emma. Számos rajzzal. (Barstow nevét tehát a magyar olvasók nem is ismerhették meg, hiába volt az írónő férje, a kötet rajzolója, sőt, lehet, hogy társszerzője...) Orczy Emma előszavát is elhagyták. Helyébe a - sajnos ismeretlen - magyar fordító bevezetője került. Ezután a kötet száz évre Csipkerózsikaálomba merült, míg végül az Imea Kiadó reprintelte, illetve felkerült a MEK-re is. Ám tulajdonképpen ma is elérhetetlen és ismeretlen könyv hazánkban. [8]

A mesékröl Orczy azt állítja az előszóban, hogy egy furcsa, régi, kis könyvböl valók, amely már piszkos és szakadt, a kötése sem a régi már, s a címe: Népmesék. Utóbbi szó magyarul szerepel az angol szövegben. Ez a bensőséges bevezetés tehát azt állítja, hogy Orczy Emmának gyermekkorában volt egy Népmesék címü kis könyve e nyolc történettel, s most ezeket fordította le angolra. Így ír: „a következőkben olvasható kis gyüjtemény segített nekem gyermekkoromban, hogy elüssek sok kellemes órát: most abban a reményben nyújtom át angol olvasóimnak - sok képpel díszítve -, hogy legalább akkora örömük származik majd a varázslat és kaland e kis tárházából, mint nekem a Népmesék ódon, szakadt példányából." Gondolható, hogy ezek után igyekeztem mindent megtenni, hogy megtaláljam ezt a magyar mesegyűjteményt: eddig azonban még nem jártam sikerrel. Jelen sorok írásakor hajlamos vagyok a hangulatos előszó állítását kedvcsináló fabulációnak minősíteni, három okból is.

Az első, hogy Orczy Emma megemlít két nevet a bevezetőjében: Jókaira és Gaálra hivatkozik, mint akik úgy teremtették újjá a „régi magyar legendákat” (Orczy kifejezése), hogy azok megismertették a világgal nemzeti gondolkodásmódunkat, miként tette ugyanezt a zenében Brahms és Liszt. Gaál György mesegyüjteményében vagy Jókai meséi között nem szerepelnek Orczy meséi (persze, az előszó nem is állít ilyesmit). A két meseíró nagyság megemlítése azonban arra utalhat, hogy Orczy az ő történeteikből merített késztetést, ihletet, hogy hasonló módon, olykor teljesen saját mese alkotásával, de a nemzeti gondolkodásmódnak megfelelve írjon saját mesekönyvet. A második ok, hogy Orczy Emma szülei külföldre költöztek, amikor lányuk még csak hároméves volt. Ha vásároltak is neki magyar mesekönyveket, mesehallgatói benyomásaiban fontosabb lehetett a szóbeliség, hiszen amikor Magyarországon élt, még egészen biztosan nem tudott olvasni.

A harmadik ok pedig, hogy a kötet történetei egyáltalán nem hasonló stílusúak, s egy részük nem is Orczy gyerekkora magyar mesekönyv-ízlésének felel meg (Erdélyi János, Kriza János, Gaál György, Jókai Mór meséinek), hanem annál sokkal modernebb. Olyan, amilyet egy az irodalomban tájékozott, olvasott, harmincéves írónő írna, amennyiben a mese müfajába tartozó munkát tervez, ráadásul angolok számára, akiknek a gyermekköltészete és sajátos gyermekabszurdja (pl. az Alice Csodaországban) sok szempontból gyökeresen eltérő a magyartól. Ilyen, modern, ám a mese szabályainak megfelelö szöveg a kötetben a The Suitors of the Fire Fly és a Mr Cuttlefish's Love Story. Emellett található keleties („ezeregyéjszakás”) történet a könyvben, a The Enchanted Cat (érdekes, hogy a magyar fordító mindössze ennél az egy mesénél nem hagyta meg Orczy Emma 
magyar címváltozatát: $A z$ elvarázsolt macskává formálva az eredeti magyar $A$ büvös macska címalakot), illetve szerepel még több, az európai mesevilágba elvezető mese, mint a The Wishing Skin - bár egy magyar mesében sosem hívnák a nyulat Mr. Bunnynak, személyként (a magyar fordító mindjárt köznévi nyulacskát is csinált belöle). Kicsit más a Nefelejts esete, amelyről maga az írónő írja, hogy a Little Snow White, vagyis a Hófehérke új életre keltése. Bár ez a történet is angolosodik (Mr. Froggal és Narcissa hercegnővel).

Végül szerepel két további mese, amelynek valóban vannak kapcsolódási pontjai a magyar meseirodalomhoz, de Grimm és az európai meseirodalom felöl. Az Uletka and the White Lizard története a magyar fordításban Iluska a kilenc törpéknél lett, ám az eredeti történet nevei (Elkabo herceg, Násztya (Nastia) királyné, és lánya, a főszereplő Uletka, a Muta nevű gonosz tündér, a jó Repto tündérkirályfi és Hobo, a manók királya) egyrészt szlávos hatást mutatnak, másrészt alighanem egyszerűen csak Orczy Emma fantáziájáról tanúskodnak. Nem csoda, hogy a magyar fordítás készítője, megfelelve a magyar mesenarráció szokásának, a szereplőket megfosztotta a nevüktöl. Uletkából lluska lett, Elkabóból „öreg herceg”, Násztyából „Iluska anyja”, Mutából „gonosz tündér", Hobóból manókirály, Reptóból tündérkirályfi, sőt a Tündérkirálynő (Fairy Queen vagy Queen) megnevezése is köznevesült. Ám épp ez a hazai sajátosság teljesen hiányzik Orczy Emmánál, akinél a fehér gyíkot sem hetedhét országon át keresik, hanem egészen Japánig utazva. Elmondható tehát, hogy ez a történet Orczy saját fikciója európai meseszereplőkkel és mesemotívumokkal. Hasonló igaz a The Twin Hunchbacksre is.

Így végigtanulmányozva a kötetet, világosan látszik, hogy minden az elöszóban elhangzó állítással ellentétben abból egyetlen, rövid történet nevezhető valóban régi magyar mesének. Ez pedig az utolsó.

\section{Az már nem igaz!}

Az eredeti kiadásban mindössze három oldalt elfoglaló, két képpel díszített rövid mese valóban olyasvalami, amit tipikus magyar mesének lehet nevezni. Napjainkban a legtöbben valószínüleg Illyés Gyula Hetvenhét magyar népmeséjéböl ismerik $A$ hiú király címen: a történetben „a király kihirdette az egész országban, hogy annak adja a lányát, aki elötte olyat tud mondani, amit ő el nem hisz." Így a leleményes Péternek, a szegény ember legöregebb fiának az a feladata, hogy akkora hazugságot mondjon az uralkodó színe előtt, amelyet az már képtelen elhinni. A beszélgetés végén, amikor arról beszél, hogy az ő apja felfogadta a király öregapját kanásznak, a hiú király már nem tud a szokásos „Elhiszem, fiam”-mal válaszolni. „Hazudsz! Akasztófára...!” - kiáltja indulatosan, s ezzel Péter el is nyeri a királylány kezét.

A novellamese Török Károly gyűjtése volt az 1860-as évekből, s Az már nem igaz! címen került be a Magyar Népköltési Gyüjteménybe 1872-ben. [9] A két szöveg, Töröké és Orczyé megegyezik a keretes, párbeszédes formában és a csattanóban is. Az azonban nem kideríthető, van-e kapcsolat a két meseváltozat között. Elképzelhető, hogy a (felnőtt) Orczy Emma ismerte a Népköltési Gyüjtemény vonatkozó kötetét (amely csak négy évvel azután jelent meg, hogy az Orczy-család külföldre távozott), s innen vette saját meséje ötletét. Az is elképzelhető azonban, hogy az írónő más, esetleg szóbeli forrásból, netán valóban gyerekkorából ismerte a mese egy másik variánsát.

Tény azonban, hogy az ő meséjében a fiú, John, és a király egészen másról beszélgetnek, $s$ hosszabban, mint az itthon gyüjtött meseszövegben. Péter tizennégyszer szól a királyhoz, John tizenhatszor. Péter hazugságai különféle paraszti, mezőgazdasági témák kifordítására épülnek, sokfélék (rengeteg tőzeg, dudva, abroszként felkapható föld, fümagból kinövő erdő). Disznópásztorkodásról csak az utolsó két megszólalás szól. Ezzel szemben John összes hazugsága a malachoz kapcsolódik, mégpedig egyetlenhez. Ez a csodadisznó („wonderful pig”) tartotta el apját, anyját, hét leánytestvérét az utóbbi húsz évben, minden nap egy sajtár tejet adott, mint bármely tehén, $s$ minden reggelihez ízletes tojásokat, az oldalából pedig John anyja minden nap egy szép szelet oldalast hasított ki, majd a hús éjjelente visszanőtt a disznóra. Egy nap eltünt a malac, majd az éléskamrában sikerült rátalálni, ahol egereket fogott. Sőt, a városba is be lehetett küldeni, hogy ezt-azt elintézzen, például ruhát varratott Johnnak és az apjának a király szabójával, s mindezt olyan aranyakkal fizette ki, amelyeket út közben szedett fel. Ám, panaszolja John, újabban egyre engedetlenebb, megtagadja a parancsokat és a szeme is romlik. Ezért kellett melléje disznópásztort fogadni: a király apját! Vagyis: az eredeti csattanó, a disznópásztorolás témája Orczy 
Emmánál visszafelé kiterjeszkedik az egész szövegre, eredetivé, abszurddá, sőt, helyenként példázatszerűvé teszi! Ezért gondolom azt, hogy ez az adaptáció is saját lelemény, amely az eredeti magyar mese bármely változata csattanójának ismeretéből kiindulva íródott meg.

Igaz tehát, amit a magyar kiadás bevezetője, szóvirágos túlzással így fogalmazott meg: Orczy Emma meséivel hozzájárult „a magyar meseköltészet virágos kertjének gazdagitásához.” Az is igaz, hogy meséi tartalmaznak kontinentális, sőt, magyar meseelemeket. De igazán ötletes és önálló adaptálónak épp az utolsó meséje mutatja, a „That's Not True”. Már csak ezért is érdemes lenne megismerni, megbecsülni meseírói tevékenységét. Hiszen külföldön sokak számára az ő tündérmeséi jelentik a magyar kultúrát! [10] Csak rajtunk, magyar olvasókon múlik, elfogadjuk, elismerjük-e Orczy Emmát magyar írónak vagy meseírónak. Ö mindenesetre annak (is) tartotta magát. Életműve és hatása pedig itt van velünk ma is, születése után 155 évvel.

\section{Irodalomjegyzék}

[1] Orczy Emmáról magyar nyelven gyakorlatilag nem létezik semmiféle friss életrajzi, szakmai összefoglalás. Legutolsóként a Magyar Életrajzi Lexikon emlékezik meg róla: https://www.arcanum.hu/hu/onlinekiadvanyok/Lexikonok-magyar-eletrajzi-lexikon-7428D/o-77160/orczy-emma-baro-771BD/. Illetve található egy szócikke a Magyar írók élete és munkáiban: http://mek.oszk.hu/03600/03630/html/o/018419.htm. Ám mindkettő csak néhány soros. A magyar Wikipédia teljesen megbízhatatlan adatokat közöl róla. Szerencsére felsorolható néhány olyan népszerü cikk, amely viszonylag megbízható információkat gyüjt össze az írónőröl. FENYVESı Zsófi: $A$ magyar nő, akiröl krátert neveztek el a Vénuszon, mégsem ismered, Dívány, 2019, https://divany.hu/offline/ 2019/03/25/orczy-emma/, L. L.: Orczy bárónö és a Vörös Pimpernel, MANDA, 2012, http://mandarchiv.hu/cikk/889/ Orczy barono es a voros Pimpernel, SzABó Sz. Csaba: A magyar bárónő, aki nélkül Batman sem létezne, nlc.hu, 2018, https://nlc.hu/szabadido/20180123/orczy-emma-batman-superman-zorro/, [N. N.]: Pimpernel a metró peronján: Orczy Emma, az ellentmondást nem türő romantikus, Magyar Idők, flagmagazin.hu, 2015, https://flagmagazin.hu/irodalmi-kavehaz/pimpernel-a-metro-peronjan, [N. N.]: Orczy Emma, a kalandos életü bárókisasszony, Cultura, 2015, https://cultura.hu/kultura/orczy-emma-a-kalandos-eletu-barokisasszony/, [N. N.]: Ki a világ legismertebb magyar írója?, Index, 2015, https://index.hu/tudomany/tortenelem/ 2015/09/24/ki a vilag legismertebb magyar iroja/. Krimivel foglalkozó blogokon viszont több összefoglaló is olvasható életéről és műveiről. A legmegbízhatóbb: Longavale: Baroness Orczy, Krimi Birodalom, 2014, http://ekonyvespolc.hu/krimi-konyvekszerzok-regenyek-novellak/krimi-ironok-baroness-orczy/. Erre pedig azért hivatkozom: [BÁRDos Dóra]: $A$ Vörös Pimpernel - modern magyar mitosz, Katherine's Bookstore, 2011, http://katherinesbookstore.blogspot.com/ 2011/12/voros-pimpernel-modern-magyar-mitosz.html, mivel a magyar fordításban megjelent művek listáját is tartalmazza, amelynek közlésére jelen tanulmányban nincs mód. Megemlíthető lenne még a pályaképek felsorolásában ez a tanulmány: BOGNÁR János: Nagy titkok kicsiny virága: a skarlát pimpernel, Ponticulus Hungaricus, XIX. évfolyam 1. szám, 2015. január, http://members.iif.hu/visontay/ponticulus/rovatok/hidverok/bognarpimpernel.html. Ennek azonban jó része, leszámítva a botanikai részleteket, a Katherine's Bookstore blog szövegének jelöletlen átvétele.

[2] A témáról ír a Krimi Irodalom blog (lásd [1]) és E. F. BLEILER: Introduction = Baroness Orczy: The Old Man in the Corner, Dover, 2018, v-ix.

[3] Agatha CHRISTIE: Bünszövetkezetben, Európa, 2012, 175.

[4] Erről a témáról például: Martin HIPSKY: Modernism and the Women's Popular Romance in Britain, 1885-1925, Ohio University Press, Athens, 2011, 115-127, Ed HULSE: From Pulp Page to Silver Screen = Johnston McCuLLY: Zorro Vol. 1, 335-343, Peter RoYston: The Hidden Hero: Baroness Orczy and the Myth of the Secret Identity, GudeWrite, 20053, http://www.portwashington.com/moveweb/Guidewrite/hiddenhero.html, Matthew David SuRRIDGE: Secret Identities and the Gothic: That Demmed, Elusive Pimpernel, Black Gate Essay, 2013, https://www.blackgate.com/ 2013/04/18/secret-identities-and-the-gothic-that-demmed-elusive-pimpernel/

[5] Pl. a Delta Vision MesterMüvek és az Attraktor Kiadó A fantasztikus irodalom mesterei és Klasszikus rejtélyes történetek sorozataiban.

[6] Saját számításaim az általam a blogomon készített bibliográfiák alapján: Katherine’s Bookstore blog (lásd [1]).

[7] “Azok a bájos mesék, melyeket ez a kötet nyújt a magyar olvasónak, idegenböl, angol földröl kerülnek — haza. Üde színekben pompázó virág, mely idegen talajban kelt ki, de a honi meleg földben fogja csak igazán terjeszteni illatát. S a ki látja, élvezi, rámondja: Igen, ez a mi kertünkből való, itt viruljon, itt illatozzék!" ORCzy Emma: Régi tündérmesék, Athenaeum, 1898, 7.

[8] A kötet angol szövegét két kiadásból használtam. Baroness ORczY: Old Hungarian Fairy Tales, Kessinger Legacy Reprints, é. n. Illetve a The Baldwin Project oldala: http://www.gatewaytotheclassics.com/browse/display.php? author=orczy\&book=hungarian\&story= front. Csak itt olvasható Orczy Emma Preface-e, amelyböl saját fordításomban idézek a tanulmányban. A kötet magyar szövegét a MEK-en lehet elolvasni. https://mek.oszk.hu/ 17700/17729/. Az Imea reprintjét korábban itt lehetett megrendelni, sajnos a müvészi szépségü képeket igen ízléstelenül kiszínezték, illetve a könyv ma már nem rendelhető: http://users.atw.hu/ imeakiado/ kiadvanyok/konyv.php?termek id=19

[9] A hiú király szövegét a MEK-röl használtam: http://users.atw.hu/gasztonlaci/mesek/lllyes Mesek/05.htm\#35. A másik szöveg: TöröK Károly (szerk.): Magyar Népköltési Gyüjtemény Il. Csongrádmegyei gyüjtés, Pest, 1872, 456-459.

[10] Több helyen egyedül az ő meséi szerepelnek tipikus magyar meseként, ajánlva a neten odalátogató mesemondóknak, szülöknek! PI.: https://fairytalez.com/region/hungarian/. 
Valamennyi, a hivatkozásokban szereplő internetes oldal utolsó letöltési ideje: 2020. február 6. 